\title{
Addressing Potential Ethical Issues Regarding the Supply of Human-Derived Products or Reagents in In Vitro OECD Test Guidelines
}

\author{
Miriam N. Jacobs ${ }^{1}$, Rosemary J. Versteegen ${ }^{2}$, Carol Treasure ${ }^{3}$ and Jennifer Murray ${ }^{4}$ \\ ${ }^{1}$ Department of Toxicology, Centre for Radiation, Chemical and Environmental Hazards, Public Health England, Chilton, OXON, UK; ${ }^{2}$ International \\ Serum Industry Association, McHenry, MD, USA; ${ }^{3}$ XCellR8 Ltd, Daresbury, Cheshire, UK; ${ }^{4}$ Life Science Group Ltd, Wilden, Bedfordshire, UK
}

\begin{abstract}
The number and scope of Organisation for Economic Cooperation and Development (OECD) in vitro test guidelines (TGs) are increasing in an effort to both improve human relevance and replace in vivo animal testing. In vitro test methods being developed for TG use are increasing the use of human based reagents in combination with or replacing animal derived reagents, and demand for human reagents is likely to grow in the near future. There are a range of issues associated with the ethical use of human reagents, particularly human serum, in the adaptation and development of in vitro TGs, especially to ensure that there is no human exploitation, legal requirements are adhered to, and that the origin of the reagent is assured. To address these concerns, the OECD has instigated a workshop on ethics, sources, availability, and traceability of human based reagents for TG purposes, to be held in March 2019. The focus is to provide guidance on acceptable sources of human serum for use in in vitro TGs, in terms of donor ethics and informed consent regarding commercial use, and quality control for safety and consistent performance, with a view to providing guidance to support the adaptation and/or development of in vitro TGs using human reagents, and to ensure that in reporting the test results to regulators, clearly defined ethical and traceability aspects are adequately addressed, for the Mutual Acceptance of Data principle to be accepted in all OECD member countries. This thought-starter provides a discussion basis to achieve those objectives.
\end{abstract}

\section{Introduction}

The OECD Test Guideline Programme agrees upon test guidelines for the hazard testing of chemicals that can be accepted by any member country under the Mutual Acceptance of Data (MAD) agreement. This saves costs to industry, not having to redo tests for different regulatory authorities, but also reduces animal use in chemical testing greatly. Indeed, the OECD Test Guideline Programme has a strong commitment to the $3 \mathrm{Rs}-$ to Replace, Reduce, and Refine animals in scientific research and toxicity testing - and the replacement of in vivo animal testing with in vitro testing has grown greatly in recent years, and is increasingly being incorporated into regulatory legislation.

Fetal bovine (or calf) serum (FBS/FCS) is most commonly used at present as a medium supplement to support the mainte- nance and growth of the cells used in many of the in vitro TGs. However, some cosmetics companies, including Lush ${ }^{1}$ and the Body Shop ${ }^{2}$, have developed policies to avoid all animal generated products, and where in vitro methods are used, there is a preference to use xeno-free materials, sourced solely from humans, in the chemical testing procedures (Xeno-free conditions are defined as those not containing any elements that are not from the same species as the cells used, in this case, human (OECD, 2018a)). In line with a major global trend towards vegan products in the cosmetics industry, a wider interest in avoiding the use of animal-derived products in testing is therefore now emerging.

Unnecessary suffering of fetuses in slaughterhouses is addressed at an international level, but consistent practical application and enforcement have been questioned. FBS has been

\footnotetext{
1 https://uk.lush.com/article/animal-testing-our-policy (accessed 14.01.2019).

2 https://www.thebodyshop.com/en-gb/about-us/against-animal-testing (accessed 14.01.2019).
}

Received January 19, 2019;

Epub February 19, 2019; () The Authors, 2019.

ALTEX 36(2), 163-176. doi:10.14573/altex.1901281

Correspondence: Miriam N Jacobs, Department of Toxicology, Centre for Radiation, Chemical and Environmental Hazards, Public Health England, Chilton, OXON,

OX11 ORQ UK

(miriam.jacobs@phe.gov.uk)
This is an Open Access article distributed under the terms of the Creative Commons Attribution 4.0 International license (http://creativecommons.org/licenses/by/4.0/), which permits unrestricted use, distribution and reproduction in any medium, provided the original work is appropriately cited. 
documented to be of particular concern due to 1) the fact that it is animal derived and 2) the manner in which it is commonly perceived to be sourced (van der Valk and Gstraunthaler, 2017, and references therein). However, the view that fetal blood is collected from live fetuses is contested by both the slaughter and the serum industries (Nielsen and Hawkes, 2019), and animal welfare aspects have been reviewed by the European Food Safety Authority (More et al., 2017). The UN World Organization for Animal Health (OIE) provides an internationally agreed code of conduct with regard to the slaughter of animals so that the unnecessary suffering of fetuses in slaughterhouses is avoided (OIE Terrestrial Animal Health Code - Chapter 7.53); also, veterinary associations such as the American Veterinary Medical Association (AVMA) have integrated such codes of conduct in their guidelines ${ }^{4}$. In practice, slaughterhouses are veterinary controlled in all countries that export meat, and normally they are audited, as are human blood collection / donor centers, but more information on global monitoring and auditing is needed.

Human based sources of medium supplements, including human serum, human platelet lysate (hPL), and human serum albumin (HSA), are viable alternatives, but there are concerns regarding the ethics in obtaining serum from human donors, and the potential for there to be only a limited number of suppliers, with respect to OECD in vitro $\mathrm{TG}$ applications.

At the time of writing, one OECD TG, TG 442D, the KeratinoSens ${ }^{\mathrm{TM}}$ assay that addresses the adverse outcome pathway (AOP) key event of keratinocyte activation in skin sensitization, has recently been approved to also include a xeno-free protocol using human serum (Belot et al., 2017; OECD, 2018a). Another, similar human serum and human antibody adaptation for TG 442E, the h-CLAT assay (Edwards et al., 2018), is currently under discussion at the OECD. Within the new EU Horizon 2020 research program initiated in 2019, further in vitro test methods are in development that are also ultimately intended for the OECD Test Guideline Programme, and that include investigations involving the use of human serum and serum-free conditions.

This thought-starter paper seeks to identify, map, and examine how to address concerns surrounding the use of human based sources of medium supplements, and thereby provide a preliminary scoping overview of the current situation regarding the availability, sources, and ethical consent for human reagents, and human serum in particular, for a selection of OECD member countries.

\section{Current situation}

At this time, while there are no global or harmonized regulations specially addressing the use of human serum for OECD test method purposes, there are regulations in individual countries that describe both quality and regulatory requirements with respect to the use of human tissues.

In Europe, human serum used within test method development and in vitro test guidelines is considered a medical device, as it is used as part of a test method where the purpose is to diagnose and prevent disease (definition provided by the UK National Health Service, Health Research Authority ${ }^{5}$ ). Whilst there are no specific legislation examples for the purposes of TGs, there are examples of relevant legislation for the US and UK, and these are provided in Table 1.

Tab. 1: Examples of how human serum is sourced by different test method developers and users, summary of OECD National Coordinator survey responses conducted in 2017

Questions arising from the information supplied are indicated in bold italics.

\begin{tabular}{|c|c|c|c|c|}
\hline Country & Human serum source & $\begin{array}{l}\text { Donor consent and ethical } \\
\text { permission considerations } \\
\text { see also Table } 2\end{array}$ & $\begin{array}{l}\text { Additional information/ } \\
\text { issues }\end{array}$ & $\begin{array}{l}\text { References } \\
\text { (accessed during } \\
\text { February 2017) }\end{array}$ \\
\hline \multicolumn{5}{|c|}{ Major global suppliers of human serum } \\
\hline North America & $\begin{array}{l}\text { Examples of suppliers of } \\
\text { human serum: } \\
\text { Innovative Research (USA); } \\
\text { Atlanta Biologicals (USA); } \\
\text { Valley Biomedical (USA); } \\
\text { ThermoFisher Scientific } \\
\text { (USA); Access Biologicals } \\
\text { (USA); RMBio (USA); } \\
\text { ZenBio (USA); Seracare }\end{array}$ & $\begin{array}{l}\text { Example of common practise among } \\
\text { suppliers: Access biologicals } \\
\text { Human } A B \text { serum: "Collections are } \\
\text { IRB approved, donors sign consents } \\
\text { and are screened for compliance to } \\
21 \text { CFR } 640 \text {, full FDA viral testing" } \\
\text { Human } A B \text { Serum: Converted: } \\
\text { "...human serum is collected } \\
\text { from donors meeting the health" }\end{array}$ & $\begin{array}{l}\text { Most suppliers originate } \\
\text { in the USA, many have } \\
\text { a network of global } \\
\text { distributors, ensuring } \\
\text { easy access to the } \\
\text { products from wide } \\
\text { geographical territories } \\
\text { across Europe, Asia and } \\
\text { beyond. Human serum }\end{array}$ & $\begin{array}{l}\text { http://www. } \\
\text { accessbiologicals. } \\
\text { com/products/cell- } \\
\text { culture-products }\end{array}$ \\
\hline
\end{tabular}

\footnotetext{
3 http://www.oie.int/index.php?id=169\&L=0\&htmfile=chapitre_aw_slaughter.htm (accessed 21.01.2019).

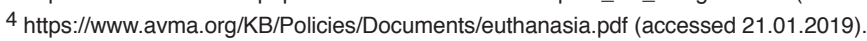

5 http://www.hra-decisiontools.org.uk/ethics/glossary.html\#M2 (accessed 12/09/2018).
}

\section{Abbreviations}

AVMA, American Veterinary Medical Association; AOP, Adverse Outcome Pathway; CRO, Contract Research Organization; FBS, Fetal Bovine serum; FCS, Fetal Calf Serum; FDA, US Food and Drug Administration; hPL, human Platelet Lysate; HAS, Human Serum Albumin; HTA, UK Human Tissue Act; ISIA, International Serum Industry Association; MAD, Mutual Acceptance of Data; MSC, Member State Committee; NHSBT, UK National Health Service Blood and Transplant; TGs, OECD Test Guidelines; OECD, Organization for Economic Cooperation and Development; OIE, UN World Organization for Animal Health; SME, Small to Medium Enterprise; WNT, OECD Working Group of National Coordinators to the OECD Test Guideline Programme 


\begin{tabular}{|c|c|c|c|c|}
\hline Country & Human serum source & $\begin{array}{l}\text { Donor consent and ethical } \\
\text { permission considerations } \\
\text { see also Table } 2\end{array}$ & $\begin{array}{l}\text { Additional information/ } \\
\text { issues }\end{array}$ & $\begin{array}{l}\text { References } \\
\text { (accessed during } \\
\text { February 2017) }\end{array}$ \\
\hline \multicolumn{5}{|c|}{ Major global suppliers of human serum } \\
\hline & $\begin{array}{l}\text { (USA); Gemini BioProducts } \\
\text { (USA); NorthBio (Canada). }\end{array}$ & $\begin{array}{l}\text { requirements established by } 21 \text { CFR } \\
640, \text { subpart G via plasmapheresis. } \\
\text { These individual units are converted } \\
\text { to serum and then pooled, filtered, } \\
\text { bottled and cell culture tested for } \\
\text { mycoplasma, endotoxin, and United } \\
\text { States Pharmacopeia (USP) sterility } \\
\text { Each individual unit is tested and } \\
\text { found negative for all required viral } \\
\text { markers via FDA-approved methods } \\
\text { as well as HTLV I/II and West Nile } \\
\text { Virus". } \\
\text { Human AB Serum: Off the Clot: } \\
\text { "Off the Clot AB serum is collected } \\
\text { from healthy male donors in the } \\
\text { United States at FDA licensed } \\
\text { facilities. It has been allowed to } \\
\text { coagulate naturally and contains no } \\
\text { anticoagulants or preservatives." } \\
\text { Human AB Serum Heat-Inactivated: } \\
\text { "...heat inactivation protocol brings } \\
\text { the temperature of the material to } \\
56^{\circ} \mathrm{C} \text { and maintains this temperature } \\
\text { for } 30 \text { minutes. Some precipitate may } \\
\text { be evident, which can be removed by } \\
\text { filtration, if desired." }\end{array}$ & $\begin{array}{l}\text { is relatively simple to } \\
\text { ship around the world, } \\
\text { because there is currently } \\
\text { no customs requirement } \\
\text { for an equivalent to the } \\
\text { veterinary certificate } \\
\text { required for FBS. Mouse } \\
\text { and donor horse and FBS } \\
\text { certificates of analysis } \\
\text { also available from the } \\
\text { website. }\end{array}$ & \\
\hline UK/SME & $\begin{array}{l}\text { Sigma Aldrich, } \\
\text { FDA-approved pooled } \\
\text { human serum } \\
\text { Global origin: Items H4522 } \\
\text { and H6914 are of US origin } \\
\text { Pool size: "We provide } \\
\text { plasma derived human } \\
\text { serum (H4522) and off the } \\
\text { clot human serum (H6914). } \\
\text { Donor pools would depend } \\
\text { on lot size, but for AB off } \\
\text { the clot, } 200 \text { is correct." }\end{array}$ & $\begin{array}{l}\text { Registration with the US FDA: "The } \\
\text { FDA does not give "approval" for } \\
\text { facilities but they have registrations. } \\
\text { The site manufacturing this material } \\
\text { is registered with the FDA. } \\
\text { Testing and guidelines: "Both H4522 } \\
\text { and H6914 are tested under FDA } \\
\text { requirements and are collected under } \\
\text { AABB guidelines." } \\
\text { Batch-to-batch consistency of the } \\
\text { product specifications: "Batch to } \\
\text { batch consistency is good, but } \\
\text { different donors in different batches } \\
\text { can always cause differences." } \\
\text { Long term supply (>5 years): "We } \\
\text { have used the current collection } \\
\text { centers for >15 years." } \\
\text { Products are class } 1 \text { medical } \\
\text { devices intended for research } \\
\text { use only. Not for therapeutic } \\
\text { applications. } \\
\text { Does research use include } \\
\text { commercial use also? } \\
\text { As freely supplied to CROs, it is } \\
\text { assumed so, but would be useful to } \\
\text { confirm. }\end{array}$ & $\begin{array}{l}\text { Certificate of Analysis } \\
\text { available }\end{array}$ & \\
\hline UK & $\begin{array}{l}\text { Supplier of human serum: } \\
\text { Life Science Group (UK); } \\
\text { Life Science Production } \\
\text { offers a wide range of } \\
\text { human material suitable }\end{array}$ & $\begin{array}{l}\text { "Human serum provides a more } \\
\text { comparable cell culture environment } \\
\text { compared with other animal sera } \\
\text { such as foetal bovine serum (FBS). It } \\
\text { is the serum of choice when working }\end{array}$ & $\begin{array}{l}\text { Certificate of Analysis } \\
\text { available: "Human AB } \\
\text { serum, male only Human } \\
\text { AB Serum is a vital cell } \\
\text { culture reagent for }\end{array}$ & $\begin{array}{l}\text { http://lifescience } \\
\text { group.co.uk/ } \\
\text { www-lifesciencepro } \\
\text { duction-co-uk/ }\end{array}$ \\
\hline
\end{tabular}

a https://www.who.int/medicines/publications/pharmacopoeia/TestForSterility-RevGenMethod_QAS11-413FINALMarch2012.pdf (accessed 18.02.2019). 


\begin{tabular}{|c|c|c|c|c|}
\hline Country & Human serum source & $\begin{array}{l}\text { Donor consent and ethical } \\
\text { permission considerations } \\
\text { see also Table } 2\end{array}$ & $\begin{array}{l}\text { Additional information/ } \\
\text { issues }\end{array}$ & $\begin{array}{l}\text { References } \\
\text { (accessed during } \\
\text { February 2017) }\end{array}$ \\
\hline \multicolumn{5}{|c|}{ Major global suppliers of human serum } \\
\hline & $\begin{array}{l}\text { for a variety of cell culture } \\
\text { sera applications including } \\
\text { pooled human (male) } \\
\text { serum from the US and } \\
\text { France, human AB serum } \\
\text { suitable for both research } \\
\text { and manufacturing; human } \\
\text { platelet lysate and human } \\
\text { platelets. }\end{array}$ & 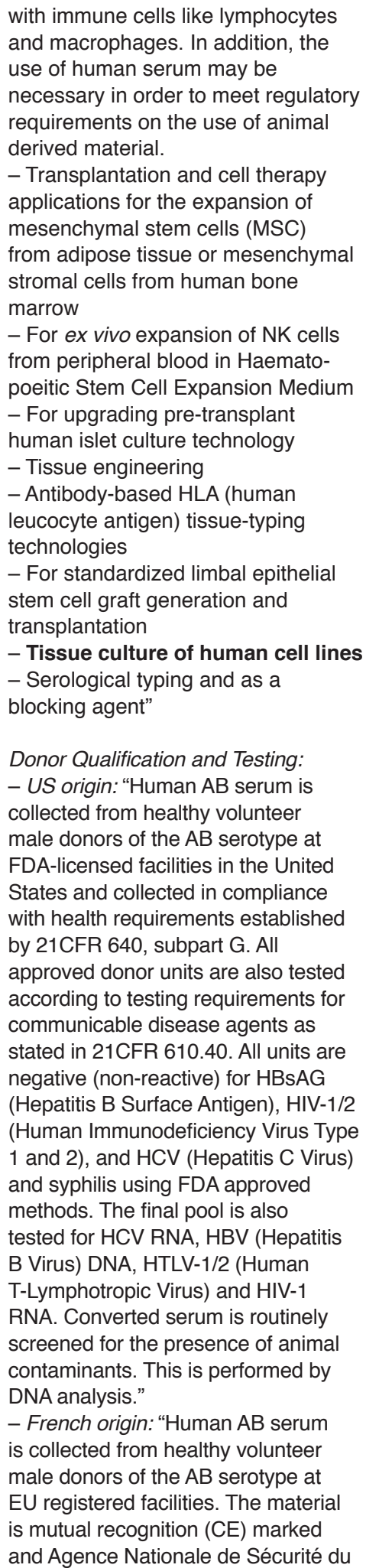 & 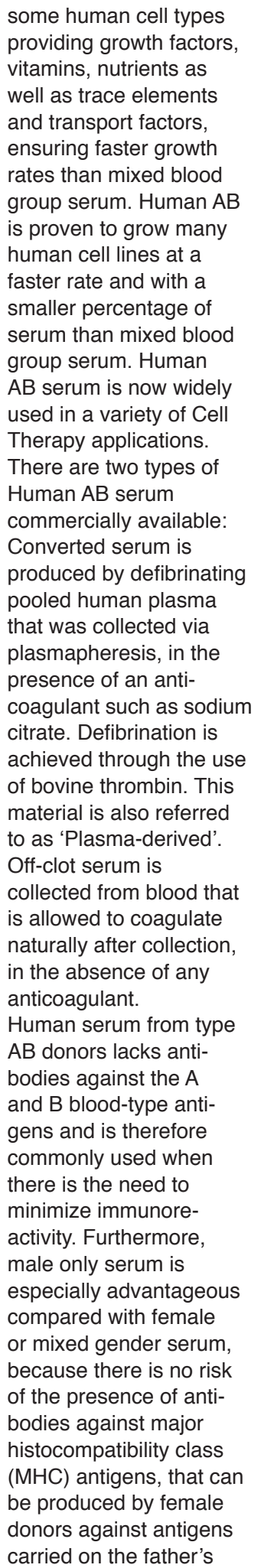 & \\
\hline
\end{tabular}




\begin{tabular}{|c|c|c|c|c|}
\hline Country & Human serum source & $\begin{array}{l}\text { Donor consent and ethical } \\
\text { permission considerations } \\
\text { see also Table } 2\end{array}$ & $\begin{array}{l}\text { Additional information/ } \\
\text { issues }\end{array}$ & $\begin{array}{l}\text { References } \\
\text { (accessed during } \\
\text { February 2017) }\end{array}$ \\
\hline \multicolumn{5}{|c|}{ Major global suppliers of human serum } \\
\hline & & $\begin{array}{l}\text { Médicament et des produits de santé } \\
\text { (ANSM) approved in vitro diagnostic } \\
\text { medical devices (IVDMD). All units are } \\
\text { negative (non-reactive) for HBsAG, } \\
\text { HIV-1/2, and HCV RNA, HTLV-1/2, } \\
\text { HIV-1 RNA and syphilis. No animal } \\
\text { derived ingredients are used in the } \\
\text { production of human AB serum." } \\
\text { Specifications } \\
\text { - US origin: "Off-Clot material typi- } \\
\text { cally requires } 200-250 \text { pre-screened } \\
\text { donors per batch. Each individual } \\
\text { donation can produce approximately } \\
200 \text { ml serum. Human AB serum } \\
\text { produced from converted plasma } \\
\text { may be manufactured from a pool } \\
\text { of material from a maximum of } 10 \\
\text { donors. It offers a more reproducible } \\
\text { product with a reduced potential risk } \\
\text { of cross infection." } \\
\text { - French origin: "Serum only } \\
\text { available as off-clot material." }\end{array}$ & $\begin{array}{l}\text { cells and/or the foetus' } \\
\text { cells during pregnancy." }\end{array}$ & \\
\hline \multicolumn{5}{|c|}{ Further sources of human serum } \\
\hline France/SME & $\begin{array}{l}\text { "- Blood as an expired } \\
\text { product in blood banks. } \\
\text { - Blood as a medical } \\
\text { waste, such as in hemo- } \\
\text { chromatosis, where blood } \\
\text { drawing is the treatment of } \\
\text { the patient. } \\
\text { - Blood collected in a } \\
\text { few blood centres that } \\
\text { maintain a cohort of } \\
\text { volunteers who do not meet } \\
\text { the criteria for giving blood } \\
\text { for therapeutic purposes, } \\
\text { e.g., too old or too many } \\
\text { transfusions, but are } \\
\text { willing to give for research } \\
\text { purposes } \\
\text { - Blood from clinical } \\
\text { laboratories that remains } \\
\text { after the dosages are } \\
\text { performed. } 1 \text { ml or less per } \\
\text { tube but large numbers of } \\
\text { tubes, that are pooled. } \\
\text { Depending on the } \\
\text { specification of our final } \\
\text { product, we rely on one } \\
\text { source or another, or we } \\
\text { pool." }\end{array}$ & $\begin{array}{l}\text { The laws that apply are those for } \\
\text { human biological product leftovers. } \\
\text { This is considered as waste and is } \\
\text { the only case where the consent of } \\
\text { the donor is not sought. } \\
\text { Should consent to use once } \\
\text { expired be included in the per- } \\
\text { mission to use? }\end{array}$ & $\begin{array}{l}\text { Hemochromatosis: First } \\
\text { drawing of the therapeutic } \\
\text { period is overloaded } \\
\text { with iron and ferritin/ } \\
\text { transferrin and in further } \\
\text { drawings, the markers } \\
\text { are normalized. }\end{array}$ & \\
\hline $\begin{array}{l}\text { Austria / } \\
\text { Government / } \\
\text { Academic }\end{array}$ & $\begin{array}{l}\text { "The use of human platelet } \\
\text { lysate (hPL) may be } \\
\text { considered which could } \\
\text { offer further advantages in } \\
\text { terms of broad availability }\end{array}$ & $\begin{array}{l}\text { "hPL is produced from out of date } \\
\text { blood products, and is easily } \\
\text { available due to the short shelf life } \\
\text { (5 days) for transfusion purposes." }\end{array}$ & $\begin{array}{l}\text { An extensive global } \\
\text { survey on hPL for cell } \\
\text { propagation has been } \\
\text { conducted and published } \\
\text { (Strunk et al., 2018a,b). }\end{array}$ & $\begin{array}{l}\text { See, e.g.: } \\
\text { Gstraunthaler et al., } \\
2015 ; \\
\text { van der Valk and } \\
\text { Gstraunthaler 2017; }\end{array}$ \\
\hline
\end{tabular}




\begin{tabular}{|c|c|c|c|c|}
\hline Country & Human serum source & $\begin{array}{l}\text { Donor consent and ethical } \\
\text { permission considerations } \\
\text { see also Table } 2\end{array}$ & $\begin{array}{l}\text { Additional information/ } \\
\text { issues }\end{array}$ & $\begin{array}{l}\text { References } \\
\text { (accessed during } \\
\text { February 2017) }\end{array}$ \\
\hline \multicolumn{5}{|c|}{ Further sources of human serum } \\
\hline & $\begin{array}{l}\text { (there are many commercial } \\
\text { suppliers (12 suppliers } \\
\text { shown in van der Valk and } \\
\text { Gstraunthaler, 2017)), } \\
\text { quality and biological } \\
\text { safety." }\end{array}$ & & $\begin{array}{l}\text { A similar global survey } \\
\text { would be useful for } \\
\text { human serum. }\end{array}$ & $\begin{array}{l}\text { van der Valk et al., } \\
\text { 2018; Strunk et al., } \\
2018 a, b\end{array}$ \\
\hline $\begin{array}{l}\text { Sweden / } \\
\text { Academic }\end{array}$ & $\begin{array}{l}\text { Out of date blood products } \\
\text { used to produce human } \\
\text { albumin }\end{array}$ & $\begin{array}{l}\text { "Human blood products, from which } \\
\text { human serum is obtained, [that] } \\
\text { are past a "use by" date, cannot } \\
\text { be used for human use, and would } \\
\text { be incinerated as waste, if not } \\
\text { repurposed." }\end{array}$ & & $\begin{array}{l}\text { Personal } \\
\text { communication }\end{array}$ \\
\hline $\begin{array}{l}\text { Japan / } \\
\text { Government }\end{array}$ & $\begin{array}{l}\text { Commercial supply } \\
\text { including Sigma / Merck. } \\
\text { Local supply of Japanese } \\
\text { serum not available. }\end{array}$ & $\begin{array}{l}\text { "Currently unknown whether the use } \\
\text { of human serum is permitted in this } \\
\text { institute." }\end{array}$ & $\begin{array}{l}\text { Small number of batches } \\
\text { available and more } \\
\text { expensive than FBS. }\end{array}$ & $\begin{array}{l}\text { Personal } \\
\text { communication }\end{array}$ \\
\hline $\begin{array}{l}\text { Switzerland / } \\
\text { Large } \\
\text { company }\end{array}$ & $\begin{array}{l}\text { Human serum available } \\
\text { - from the blood bank \& } \\
\text { probably other sources }\end{array}$ & $\begin{array}{l}\text { "Current understanding is that there } \\
\text { are no restrictions on blood donation } \\
\text { for life science applications, or any } \\
\text { customs restrictions on the import of } \\
\text { commercial blood products of human } \\
\text { origin. Import permits can easily be } \\
\text { obtained from the Government." }\end{array}$ & $\begin{array}{l}\text { Expired donations from } \\
\text { the blood bank have been } \\
\text { used in the past and were } \\
\text { easy to obtain. } \\
\text { Not aware of any cultural } \\
\text { barriers or restrictions. }\end{array}$ & $\begin{array}{l}\text { Personal } \\
\text { communication }\end{array}$ \\
\hline
\end{tabular}

Methodologically, for time and resource reasons, the authors utilized selected reviews and followed up directly with the OECD National Coordinators and their contacts. This paper does not therefore provide a comprehensive global review, but does show that for several OECD member countries, whilst there are some outstanding issues to address, it should be possible in the future to satisfactorily address concerns regarding the ethical supply and use of these materials.

\section{What are the needs and concerns of the relevant parties?}

There is a need to ensure that the commercial use of human serum, for example by Contract Research Organisations (CROs) in TG protocols, meets the varying ethical and legislative requirements and guidance specifications in place in OECD member countries. There appear to be six core elements to the ethical discussion. These relate to:

(i) Any health-related aspects of the donation procedure;

(ii) permission from the donor for commercial use;

(iii) payment of the donors and the potential for exploitation of low-income populations;

(iv) overarching data protection of the donors;

(v) a practical concern of sufficient supply of human based reagents from more than one commercial source, so that there is both no "monopoly" in supply, but also so that supply can be ensured, whilst protecting the clinical supply chain, and not competing with medical needs; (vi) Cultural perceptions in relation to human organ (including blood) donation and in vitro chemical testing.

\section{(i) Health-related aspects of the donation procedure: tissue screening and need for post manufacturing treatment of human serum}

Human products are screened for a certain panel of viruses in line with the regulations pertaining in the country of collection, but this applies only if material is collected from a registered donor center. If collected elsewhere, viral testing is not assured. Generally, all commercial human serum, HSA, and hPL products are screened for viruses including HBsAG (Hepatitis B Surface Antigen), HIV-1/2 (Human Immunodeficiency Virus Type 1 and 2), HCV (Hepatitis C Virus), and syphilis using FDA approved methods. The final pool is also tested for HCV RNA, HBV (Hepatitis B Virus) DNA, HTLV-1/2 (Human T-Lymphotropic Virus) and HIV-1RNA. They are also screened for mycoplasma infection, etc. Typical examples of certificates of analysis are provided by reputable suppliers. Laboratory work with commercial human serum, HSA, and hPL products requires strict use of biosafety hazard cell culture hoods, where FBS does not.

It also needs to be clarified that material is required to be tested for only certain viruses. A pool of donor material, such as that used to produce HSA, pooled serum, and plasma products, etc., can be made up from donations from many hundreds of donors, and each of these can be carrying viruses that are not on the test panel.

The ISIA have conducted extensive work on the gamma irradiation of serum intended to mitigate the risk of introducing adventitious contaminants into cell cultures and thereby improve 
Tab. 2: Examples of responses received regarding how the ethical considerations in the use of human serum are currently addressed in selected OECD member countries

Questions arising from the information supplied are indicated in bold italics.

\begin{tabular}{|c|c|c|}
\hline $\begin{array}{l}\text { Country/ } \\
\text { Government }\end{array}$ & Donor consent and relevant ethical permission considerations/legislation & References \\
\hline $\begin{array}{l}\text { UK / } \\
\text { Government }\end{array}$ & $\begin{array}{l}\text { "In the UK, the Human Tissue Act } 2004 \text { sets out the legal requirements for consent } \\
\text { for the removal, storage, and use of human organs and tissue for scheduled purposes } \\
\text { in England, Wales, and Northern Ireland. Legal requirements for Scotland are set out } \\
\text { in the Human Tissue (Scotland) Act } 2006 \text {. The Human Tissue Authority (HTA) is the } \\
\text { regulatory body that oversees the consent and licensing requirements set out in the } \\
\text { Act. A number of factors are relevant when considering whether consent is legally } \\
\text { required for the removal and use of human material: } \\
\text { Firstly, the purpose for which the material is removed or donated, as only scheduled } \\
\text { purposes as defined in the Act are within scope. For example, when material is } \\
\text { donated by the living for performance assessment or quality assurance purposes, } \\
\text { the consent requirements do not apply as these activities are not considered as } \\
\text { scheduled purposes under the Act when the material is donated by the living. } \\
\text { A further consideration is whether the material in question is considered as "relevant } \\
\text { material" as defined in the Act - "material other than gametes, which consists of, or } \\
\text { includes, human cells". Human serum is normally not considered as relevant material, } \\
\text { as centrifugation is expected to remove intact human cells from the resulting serum. } \\
\text { Further information on consent for the removal of relevant material is available in the } \\
\text { HTA Code of Practice A on Consent. } \\
\text { Another consideration is that the consent provisions of the Act do not apply to imported } \\
\text { material. However, the HTA considers it good practice to ensure mechanisms are in } \\
\text { place in the source country for obtaining consent. Further information on imported } \\
\text { material is available in the HTA Code of Practice E on Research, paragraphs } 98-114 \text {. } \\
\text { There are also a number of consent exceptions when relevant material is used for } \\
\text { research purposes, these are set out in paragraphs } 56-69 \text { of Code E." }\end{array}$ & $\begin{array}{l}\text { Human Tissue Act } 2004 \\
\text { accessed on } 14 \text { February } \\
2018 \text { http://www.legislation. } \\
\text { gov.uk/ukpga/2004/30/ } \\
\text { contents } \\
\text { HTA Code of Practice A on } \\
\text { Consent. https://www.hta. } \\
\text { gov.uk/sites/default/files/ } \\
\text { HTA\%20Code\%20A_1.pdf }\end{array}$ \\
\hline $\begin{array}{l}\text { UK / Medical } \\
\text { Research } \\
\text { Council }\end{array}$ & $\begin{array}{l}\text { "Consent (or authorisation) for the use of human biological material in research, } \\
\text { where appropriate, is an integral part of UK tissue legislation; it is one way to deliver } \\
\text { transparency and foster trust between researchers and participants; and so should } \\
\text { be sought in most situations. Whenever seeking consent, the information provided } \\
\text { to potential donors should be proportionate and understandable, supporting the } \\
\text { participant to make the decision to donate or not. Appropriate consent is based } \\
\text { on the principle that competent individuals are entitled to choose freely whether } \\
\text { to participate in research and should be given appropriate information to be able } \\
\text { to make this choice. As an additional safeguard, it should be complemented by } \\
\text { independent ethical review of the consent process and proposed protocol. } \\
\text { It is important that there is clarity of arrangements for allowing commercial access to } \\
\text { human biological material originally donated for research projects... Where possible, } \\
\text { participants should know when their sample or products derived from it may be } \\
\text { used by the commercial sector, and the potential benefits of this access. It is also } \\
\text { important to let the participant know they will not be entitled to a share of any profits } \\
\text { that might ensue, as is also the case for IP rights generated from sample use in the } \\
\text { academic sector." }\end{array}$ & $\begin{array}{l}\text { Human Tissue and Biological } \\
\text { Samples for Use in } \\
\text { Research: Operational and } \\
\text { Ethical Guidelines. Medical } \\
\text { Research Council (MRC), } \\
\text { UK (2014). https://www.mrc. } \\
\text { ac.uk/publications/browse/ } \\
\text { human-tissue-and-biological- } \\
\text { samples-for-use-in-research/ }\end{array}$ \\
\hline $\begin{array}{l}\text { USA / } \\
\text { Government: } \\
\text { Food and Drug } \\
\text { Administration } \\
\text { (FDA) }\end{array}$ & $\begin{array}{l}\text { "Within the FDA, the Center for Biologics Evaluation and Research (CBER) is } \\
\text { responsible for regulating blood products for transfusion and the manufacture } \\
\text { of pharmaceuticals. It is not currently clear whether they also cover life science } \\
\text { applications." }\end{array}$ & $\begin{array}{l}\text { US CFR } 640 \\
\text { https://www.gpo.gov/fdsys/ } \\
\text { pkg/CFR-2001-title21-vol7/ } \\
\text { pdf/CFR-2001-title21-vol7- } \\
\text { part640.pdf }\end{array}$ \\
\hline $\begin{array}{l}\text { USA: Code } \\
\text { of Federal } \\
\text { Regulations } \\
\text { (CFR) }\end{array}$ & $\begin{array}{l}\text { "Within the US Code of Federal Regulations, } 21 \text { CFR } 640 \text { covers the requirements } \\
\text { for informed consent from donors of human blood products. The text of the regulation } \\
\text { covers a requirement for donors to be fully aware of any health implications of the } \\
\text { donation procedure." } \\
\text { It does not appear to state a requirement to provide information on the potential } \\
\text { commercial or research use of the donated blood or its components. } \\
\text { "The written consent of a prospective donor shall be obtained after a qualified licensed } \\
\text { physician has explained the hazards of the procedure to the prospective donor... } \\
\text { The explanation shall consist of such disclosure and be made in such a manner that } \\
\text { intelligent and informed consent be given and that a clear opportunity to refuse is } \\
\text { presented." }\end{array}$ & $\begin{array}{l}\text { https://www.gpo.gov/fdsys/ } \\
\text { pkg/CFR-2001-title21-vol7/ } \\
\text { pdf/CFR-2001-title21-vol7- } \\
\text { part640.pdf }\end{array}$ \\
\hline
\end{tabular}


safety (Brown et al., 2018; Croonenborghs et al., 2016; Versteegen et al., 2016).

Follow up: Develop an obligatory checklist based upon the information from ISIA to include the above screening tests.

\section{(ii) Permission from the donor for commercial use}

Major global human serum suppliers generally source in the US, where the donors may be paid and provide consent forms, and in Europe, where the donors are generally not paid and consent forms are provided to and signed by the donor. With respect to the UK Human Tissues Act 2004, which lists the relevant factors for considering whether consent is legally required for the removal and use of human material, only scheduled purposes defined in the Act are within scope.

Where material is collected from paid donors, such donors are often on a low income, and in need of the income. This drives them to donate in several donor centers, and their health status is not always of the highest. In the US and the UK, coordination of donation registries does monitor individual donations within specific time limits, and alerts the blood collection centers where these are being exceeded.

Where material such as human serum and human platelets for the manufacture of hPL is donated by the living for performance assessment or quality assurance purposes, the consent requirements do NOT apply, as these are not considered to be scheduled activities under the Act.

It must be noted that human serum is normally not considered as "relevant material" as centrifugation removes intact human cells from the resulting medium.

While it is considered good practice to ensure mechanisms are in place in the source country for obtaining consent, consent exceptions do exist when relevant material is used for research purposes, and not for clinical purposes, as shown in the examples in Table 2.

Follow up: Work on this issue might need to include direct approaches to collection centers and further examination of consent forms. Development of explanatory information for the donors will be required.

\section{(iii) Payment of the donors and the potential for exploitation of low-income populations}

Donors are commonly paid in the US, but not in Europe. Whilst globally there are serious concerns and legislation in place in an attempt to prevent human organ trafficking and exploitation of vulnerable populations, the legislation in place in the US and UK does not consider human extracted blood products to fall within the legal requirements (Tab. 1). However, the customer service guide for the use of blood products for non-clinical purposes provided by UK National Health Service Blood Transfusion (NHSBT) for organizations seeking access to donated human material for non-therapeutic use, specifically stipulates that currently the NCI supply chain does not permit the issue of donated material for use as a tissue culture medium supplement (NHSBT, 2018). However, there are good indications that this could be revised (See (v) below).
Follow up: Develop an understanding of global procedures for payment of donors

\section{(iv) Data protection of the donors}

Data protection is also an increasingly important issue, for example, the General Data Protection Regulation (GDPR) came into force in the UK on May 25, 2018 and significantly increased expectations in this area. In the US, the HIPAA regulations, addressing health data protection, would be expected to have relevance to the serum donation process.

\section{Follow up: Understand global data protection requirements}

\section{(v) Competition with altruistic therapeutic donation}

This is a broader question that also applies to the supply of key elements in other TGs, but several sources of human serum are provided in Table 2 .

Medical uses of human blood donations include well known blood transfusion needs, and the derivation of therapeutic blood plasma to manufacture albumin and gamma globulin, both of which are in high demand for hospital usage. These donations are also critical for the cell therapy market, where for human treatment purposes, tests need to be developed and propagated using fresh human blood products.

With increasing use of human serum/products for OECD Test Guideline Programme purposes, there could be increased competition in the availability of these resources. For example, as indicated in iii) above, in the general guidance provided by the UK NHSBT for organizations seeking access to donated human material for non-therapeutic use, it is stated that currently the NCI supply chain does not permit the issue of donated material for use as a tissue culture medium supplement. (NHSBT, 2018).

However, there are instances where blood donations are not adequate for therapeutic uses, and where blood is classified as medical waste. This waste off-the-clot whole blood could be reclassified and potentially become a good source for serum extraction for non-clinical uses, particularly with respect to the OECD Test Guideline Programme.

In Japan, blood donations are less common than in other geographies at less than $1 \%$ of the population, compared to $3.5 \%$ in other parts of the world, according to WHO statistics for 2010 . Hence the likelihood of sufficient waste material being available for production of human serum is likely to be low to non-existent in Japan.

In the UK, $2 \%$ of donated whole blood becomes medical waste. Indicative figures for volume and frequency of use are needed to ensure availability of supply (NHSBT, 2018).

There is a responsibility on CROs to ensure compliance by using human serum and other human-derived reagents from a reputable source. Currently, there is a need for a clear framework to guide test laboratories through this process. This work is in progress in regard to animal derived materials, and is being initiated for human serum products by the International Serum Industry Association (ISIA).

Follow up: Work to ensure that wherever possible blood donations that would otherwise be considered waste and disposed of, 
should be the priority source for the production of human serum, assuming that they meet all the requirements as a raw material. There should however be systems put in place to ensure that there is no competition with clinical and therapeutic applications.

\section{(vi) Cultural perceptions in relation to human organ (including blood) donation, and in vitro chemical testing} At its best, "science" is considered to be an objective way to gather evidence that transcends most cultural and religious differences. To avoid subjective bias, good practice in scientific lines of inquiry has given rise to gold standards of well controlled study designs, informed consent, and appropriate statistics. While objectivity is the goal of scientific investigation, cultural bias can cause unexpected and unconscious subjectivity to encroach on scientific routes of enquiry.

Within Western belief systems, aside from a very small number of minority religious groups, it is assumed that it is ethically acceptable and indeed scientifically preferable to use human tissues, so long as there is no detriment to the human source or, in the case of organ donation, the person is deceased (excepting kidney donation, but this is outside the scope of this paper). Countries that have Catholicism as the state religion that hold to the sanctity of life before birth, such as Italy, do not hold with the use of human fetal stem cells.

We are seeing increased public concern regarding the use of animals in science, and the growth of animal welfare considerations has led to and been integrated into Directives and also legislative requirements in the EU, particularly Directive 2010/63/ EU revising Directive 86/609/EEC on the protection of animals used for scientific purposes. The Directive is firmly based on the principle of the 3 Rs to replace, reduce, and refine the use of animals used for scientific purposes. The 3 Rs do not specifically call out material derived from animals that is a by-product of another industry, such as the meat industry. Whilst it is recognized that we have a duty to use all by-products from the slaughter process to the maximum, to reduce waste, and to add value to those animals that are slaughtered for human consumption, it is also recognized that suffering of the fetus should be avoided (More et al., 2017, Nielsen and Hawkes, 2019; van der Valk et al., 2018).

In the EU, the cosmetics sector is the first manufacturing sector, where in vivo animal testing is specifically prohibited. The EC Cosmetics Directive, Chapter V, Article 18 specifies, without prejudice, that animal in vivo testing is prohibited, and only alternative validated methods should be used prior to placing the final formulation on the market ${ }^{6}$.

Such alternative test methods include in vitro test methods that may use materials of animal origin, such as FBS, and animal derived antibodies. They also include in silico based analysis of existing data and "read across"7 (As stated previously, some companies have developed policies to avoid all animal generated products, and where in vitro methods are used, they are only prepared to use xeno-free materials in the chemical testing.)

In Japan, the Shinto and Buddhist faiths predominate. Over $53 \%$ of the population adhere to Shinto beliefs of purity and the wholeness of the physical body. The human body and tissues thereof are sacred. Anything connected with death or the dead is considered particularly polluting. Whilst legal in Japanese law since 1997, and eased in 2010 by the Organ Transplant Act $^{8}$, according to Shinto tradition organ transplantation is not acceptable after someone has died, and this is very much reflected in practice in the World Health Organisation deceased organ donation statistics in Japan, which are far lower than in other developed economies (overall $0.83 \%$ in 2010 compared to $3.52 \%$ globally ${ }^{9}$.) Shintoism impacts also upon living donations, such that blood donation in Japan comes from less than $1 \%$ of the population ${ }^{10}$.

Thus, in Japan, with a preference for the use of domestically produced reagents in chemical testing, and with blood donations in very short supply, competition with non-therapeutic uses of human blood and serum will be detrimental to clinical uses, and animal sourced products are ethically far more acceptable than human sourced products.

In Japan, numbers of animals used in in vivo testing are minimized as far as statistically reasonable, and are generally harmonized with OECD and ISO standards. The sacrifice of life by the test animals is highly respected: commonly animal in vivo laboratories and organizations running in vivo studies have Shinto shrines and traditional ceremonial days to mark respect and reverence.

\section{To what extent have these issues been addressed in the OECD Good In Vitro Method Practices document?}

The use of human serum for cell culture applications is already referenced in the Guidance Document on Good In Vitro Method Practices (GIVIMP) (OECD, 2018b). This discussion does not go into great detail on the sources and ethics, but most major points are briefly addressed. Additional relevant references, particularly regarding hPL, are provided therein and in Table 2.

The GIVIMP states "Furthermore, it is recommended to develop new in vitro methods with a serum-free, chemically-defined medium, to avoid potential sources of uncertainty that may be introduced by using animal serum." While it is agreed that this is an ideal approach for the longer term, it is important to recognize that, for many cell types, serum-free or chemically-defined media do not yet exist, and their development is extremely time-consuming and expensive, which the GIVIMP document acknowledges (OECD, 2018b). Commercial organizations are not willing to spend years investing in the development of a defined medium,

\footnotetext{
6 https://eur-lex.europa.eu/legal-content/EN/TXT/?uri=CELEX:02009R1223-20160812\&from=EN (accessed 14.01.2019).

7 http://www.oecd.org/chemicalsafety/risk-assessment/oecd-qsar-toolbox.htm; https://echa.europa.eu/support/registration/how-to-avoid-unnecessarytesting-on-animals/grouping-of-substances-and-read-across (accessed 14.01.2019).

8 http://www.jotnw.or.jp/english/index.html (accessed 14.01.2019).

9 http://www.transplant-observatory.org/summary/ (accessed 14.01.2019).

10 https://www.who.int/bloodsafety/publications/9789241599696_eng.pdf (accessed 14.01.2019).
} 
only to then give away the composition. Furthermore, the development of these types of media is a relatively low priority for funding bodies.

While there are also issues with components of chemically-defined medium giving rise to batch-to-batch variability and performance, these are minimal compared with serum, if sourced from the same supplier. While such media may provide the potential for optimal reproducibility between experiments, it could also be argued that synthetic, defined media may not be able to match the realistic level of representation of a human population provided by the use of pooled serum from a large number of human donors. In the context of regulatory safety testing, variability between donors may be viewed as a realistic reflection of the human population and a pooled product reflects this variation.

The GIVIMP states in the context of human serum that, "The same critical points, e.g. batch-to-batch variability, as for any serum-derived products hold true. These issues are compounded by the reduced availability of large-scale batches and high variability of batches due to the diversities of human donors, which should be taken into consideration when using human serum." It is worth noting, in this context, that pooled human serum is available in lots containing material from multiple donors. As already mentioned, such sources may be assumed to provide a good "average" indication of the human population - a major scientific advantage in terms of regulatory safety testing. However, it is acknowledged that this could complicate the ethical clarity as all of these donors must be shown to have given appropriate consent. Thus, a batch of 50 liters of human serum may have donations from as many as 250 donors, with each donor giving a maximum of $500 \mathrm{ml}$ blood, which translates into 200-250 ml serum. CROs currently depend on a single statement from the supplier to cover the whole batch, so it is vital that appropriate traceability measures can be clearly demonstrated by the serum suppliers.

In some applications, the use of human serum in cell culture may be expected to provide a superior in vitro model of human physiology compared with animal sera. For example, as cited in the GIVIMP (OECD, 2018b), "FCS compared to autologous (human) serum has been found to induce a more differentiated and less stable transcriptional profile in human bone marrow mesenchymal stem cells, particularly at late passages, as shown by analysis of genome-wide microarray analysis" (Shahdadfar et al., 2005).

\section{To what extent have these issues been addressed through other information sources?}

With respect to ensuring consistent commercial sources of human serum, and the need to avoid reliance on a single supplier, discussions were initially focused on the "FDA-approved supply" from Sigma Aldrich (now Merck). Subsequent investigations have confirmed a large number of other commercial sources, some examples are shown in Table 1. Many of these suppliers are also certified members of the International Serum Industry Association (ISIA) (see Section 6). While most suppliers originate in the USA, many have a network of global distributors, ensuring easy access to the products from wide geographical territories across Europe,
Asia and beyond. Human serum is relatively simple to ship around the world, because there is currently no customs requirement for an equivalent to the veterinary certificate required for FBS. This makes human serum easier to transport but also more difficult to control in this context. Greater control is needed on the importation of human serum to ensure future traceability.

The dominance of the US market in terms of global supply raises the particular importance of understanding the details of the ethical process in the US. Certificates of Origin from suppliers may include a statement such as "All donor units are collected in donor centers in the US which are licensed by the FDA" (example taken from Sigma/Merck). It is important to understand what such statements mean in terms of the detail of the informed consent process. It is currently understood that the FDA is not directly involved in the ethics of donation and informed consent during its inspection and approval of collection centers. Furthermore, preliminary investigations suggest that the responsibility for the specific content of consent forms rests with individual collection centers in the US.

In Europe, there is a standardized approach to informed consent. In France there are examples of collection of serum as part of medical waste, and in the UK, Sweden, and Austria serum products are generated from out of date blood donations. A cluster of collection centers exists in Germany, for which one consent form, which is known to comply to the European standard, states about the donated blood: "its components are used in the context of patient care; in rare cases the blood or the components are used for standardization purposes as well as for quality control or for research and development projects." (Personal communication).

CROs require access to a consistent commercial supply of human serum, with full ethical and quality control (QC) approval, especially for regulatory work. Certified members of the International Serum Industry Association (ISIA) (https://www.serumin dustry.org) must adhere to a strict code covering both full traceability and consistent product quality. As stated in the GIVIMP document (OECD, 2018b), "Ideally, sera should be obtained from vendors that can provide traceability certification from industry bodies such as the International Serum Industry Association (ISIA)." ISIA is also US-based but has a global membership and global influence. However, a traceability scheme specifically for human serum is not yet available through this organization (see note in Section 6.1).

\section{Issues requiring further elucidation}

Figure 1 provides a simplified overview of the production of human serum and the necessary traceability, auditing, geography, and import/export checks necessary for each stage of the production line.

\subsection{Instigation of a traceability audit scheme for human serum}

Whilst a traceability audit scheme for FBS has been developed by ISIA and implemented over the last 10 years, this is not yet the case for human serum. This is currently under discussion and in- 


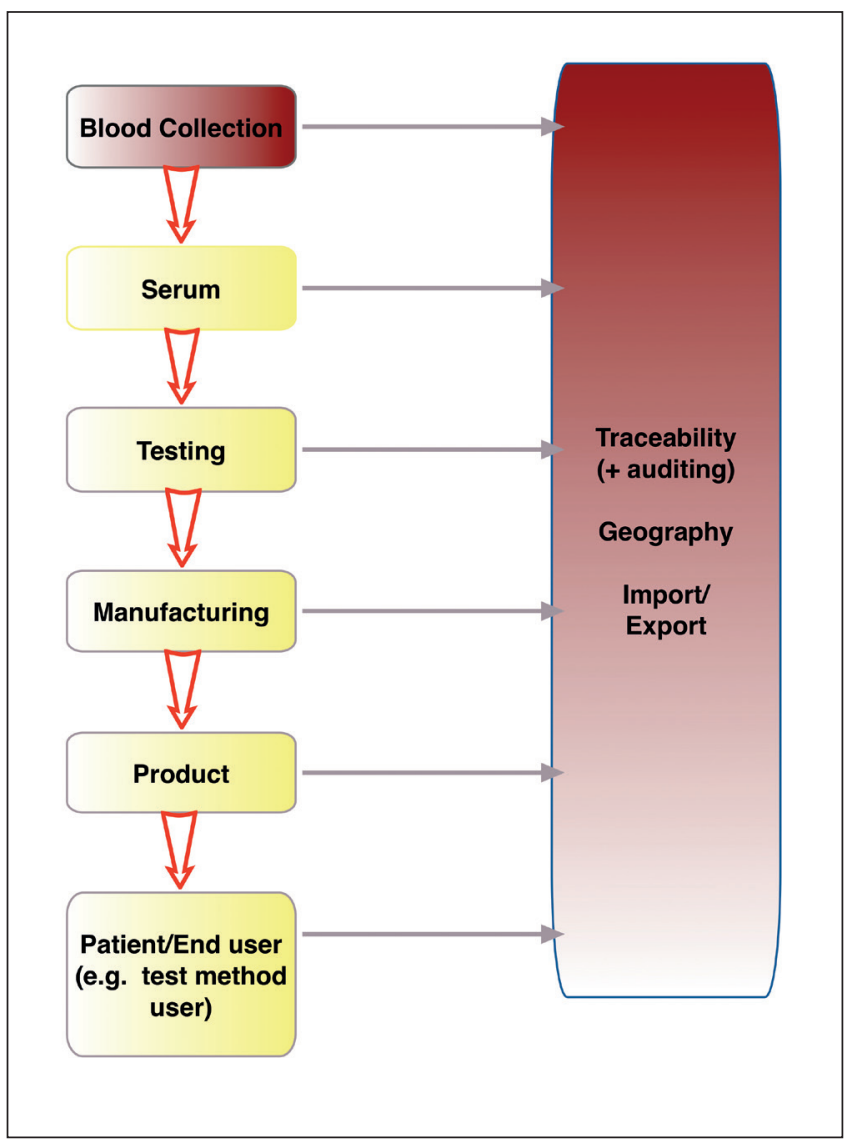

Fig. 1: Overview of the production of human serum and the necessary traceability, auditing, geography, and import/ export checks necessary for each stage of the production line Note that testing is carried out on individual donor units after collection, and throughout the process.

vestigation, and would apparently be straightforward to instigate, following the model established for FBS. This expansion of the protocol would involve expanding the front end of the existing system to include informed consent verification and other, as yet unclear, details. A commitment from the ISIA to institute such an audit scheme will include fair, reasonable, and non-discriminatory ("FRAND") terms (as recommended in OECD draft guidance 2018, currently unpublished, revised in February 201911) in their membership/associate membership subscription fees.

\subsection{Informed consent}

Alternate possibilities need to be accepted until this program becomes active, such as purchasing the serum from a reputable commercial source with an appropriate certificate of origin that includes an ethical statement, and specifically addressing donor consent to be provided. This could also be requested from suppliers of human serum made from out of date batches, and from material generated from medical treatments. This will require the inclusion of specific wording relating to the potential commercial use of the donated blood.

Follow up: Should this be sought across all member countries where human serum is collected for commercial / research applications?

Follow up: Clarification with the FDA Center for Biologics and Research regarding the approach to regulation/ standardization of the informed donor consent process in the US, and also the role of the US Health Insurance Portability and Accountability (HIPAA) regulations

Follow up: Request further additional detailed input from OECD member countries

\subsection{Information on local differences}

Whilst Table 2 provides a selected and preliminary overview of common supply, it would be useful to gain a better understanding of the similarities and differences between expectations in North America, Asia, and Europe. It is noted that the two dominant geographical sources of human serum for research and commercial use worldwide are the US and Europe. A structured approach to inviting further detailed input from member countries regarding local issues would be valuable. Information on local sources of human serum, how it is regulated to ensure ethics and performance, customs restrictions on import and cultural expectations would be very useful to elucidate further to gain a truly international picture of any challenges faced.

\section{Discussion of issues to consider before initiating further work at the OECD}

In April 2018, the OECD Working Group of National Coordinators to the Test Guideline Programme (WNT) requested that the (forthcoming) workshop "Ethics and the use of human reagents in OECD test guidelines" in March 2019 will be in accordance with, and expanding upon, the OECD GIVIMP (OECD, 2018b), on the use of human serum within the OECD Test Guideline Programme, such that evidence of ethical considerations focusing on sourcing of human blood derived products such as serum, should be included with the test report. Failure to adequately and satisfactorily address and meet the criteria will result in non-acceptance (non-compliance) of the test method results by OECD member regulatory authorities.

Essential components will be:

- Demonstrated membership of traceability audit scheme

- Provision of certificate of origin of human serum specifying:

- Donor permission freely given

- Any compensation received by the donor (e.g., payment)

- Source (i.e., preference for: out of date blood product/ medical waste, not fresh, that has been sourced primarily for medical needs)

Building upon the overview of the production of human serum and the necessary traceability, auditing, geography, and import/export

11 https://bit.ly/2DV7U7N 
Tab. 3: Preliminary suggested format for the key considerations for information requirements concerning the origins of human serum and human reagents used in in vitro cell culture for OECD test guideline purposes to be submitted with the test results to regulatory authorities

\begin{tabular}{|c|c|c|c|}
\hline Area of focus & Ethics and safety issues & All materials of human origin & $\begin{array}{l}\text { Additional comments/ } \\
\text { observations }\end{array}$ \\
\hline \multirow{12}{*}{$\begin{array}{l}\text { Blood collection } \\
\text { centre and } \\
\text { geographical } \\
\text { location }\end{array}$} & Source & + & \\
\hline & Sex & + & \\
\hline & Payment or altruistic donation & + & \\
\hline & Number of donors & + & \\
\hline & Health status & + & \\
\hline & Quarantine results & + & \\
\hline & Specific pre-treatment & + & \\
\hline & Biosafety classification & + & \\
\hline & Organ/tissue of origin & + & \\
\hline & Isolation technique & + & \\
\hline & Date of isolation/extraction & + & \\
\hline & Operator & + & \\
\hline \multirow[t]{12}{*}{ Supplier } & Informed consent paperwork & + & \\
\hline & Material transfer agreement & + & \\
\hline & Medical history of donors? & + & \\
\hline & Pathogen testing & + & \\
\hline & Shipping conditions & + & \\
\hline & Quarantine status & + & \\
\hline & Export notifications & + & \\
\hline & Import notifications & + & \\
\hline & State of material on arrival & + & \\
\hline & Biosafety classification & + & \\
\hline & Authentication & + & \\
\hline & $\begin{array}{l}\text { Demonstrated membership of } \\
\text { traceability audit scheme }\end{array}$ & + & \\
\hline $\begin{array}{l}\text { Test method/TG } \\
\text { user }\end{array}$ & $\begin{array}{l}\text { Evidence of and compliance with } \\
\text { all of the above for completion } \\
\text { of documentation required for } \\
\text { submission of test results to } \\
\text { Regulatory body }\end{array}$ & + & \\
\hline Data submitter & $\begin{array}{l}\text { Evidence of and compliance with } \\
\text { all of the above for completion } \\
\text { of documentation required for } \\
\text { submission of test results to } \\
\text { Regulatory body }\end{array}$ & + & \\
\hline $\begin{array}{l}\text { Regulatory } \\
\text { authority }\end{array}$ & $\begin{array}{l}\text { Compliance check that ethical } \\
\text { checks have been carried out in } \\
\text { accordance with recommendations } \\
\text { and MAD }\end{array}$ & + & \\
\hline
\end{tabular}




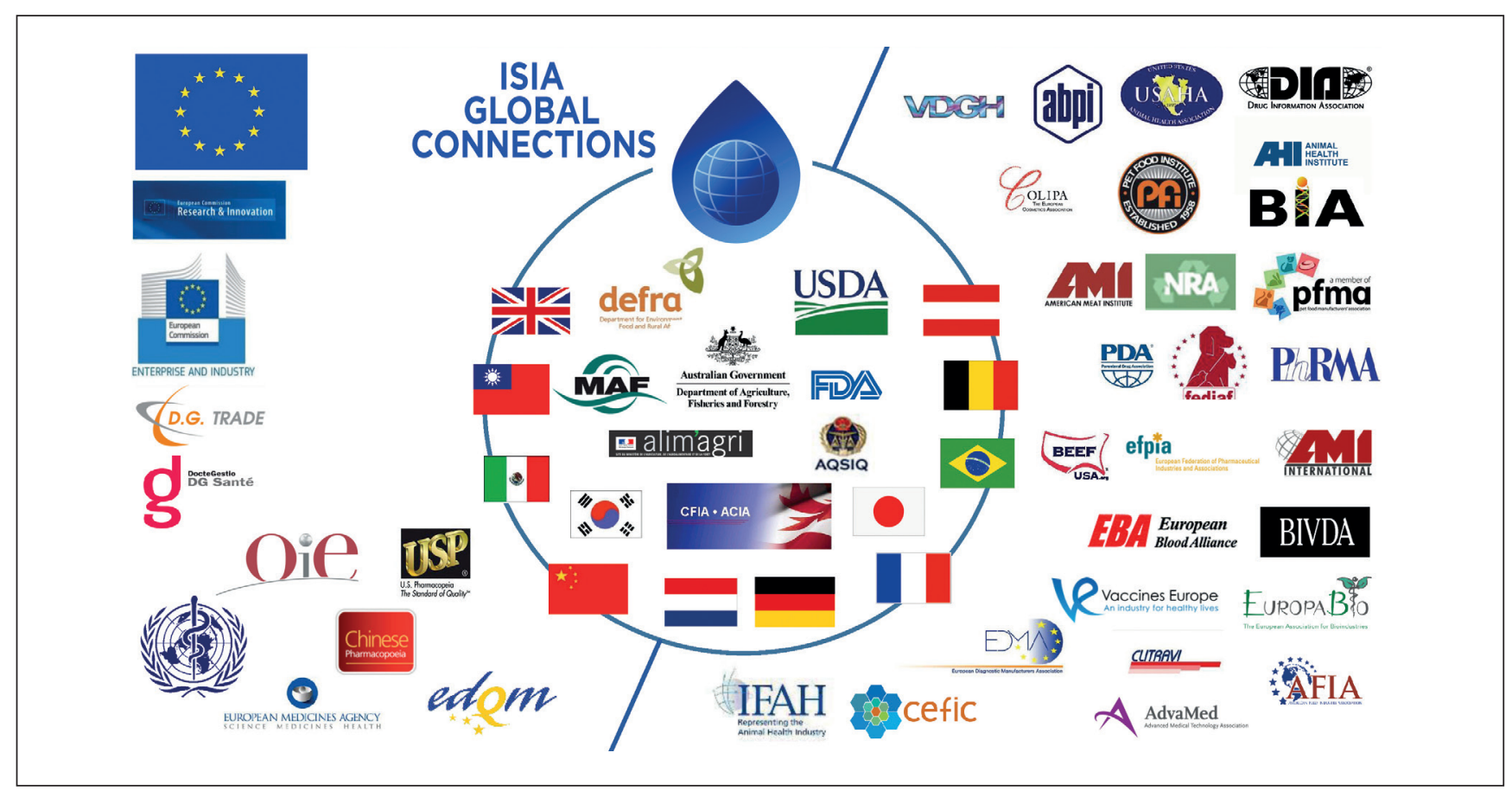

Fig. 2: Overview of the International Serum Industry Association Global Network

Reprinted with permission from ISIA.

checks necessary for each stage of the production line, Table 3 provides a more detailed overview of likely key data requirements for these essential components concerning the origins of human reagents used in in vitro cell culture for OECD TG purposes to be submitted with the test results, to regulatory authorities.

It is therefore proposed that where versions of "me-too" or "xeno-free" modified test guidelines specify the use of human serum, they should state that users may only obtain human serum from certified companies, i.e., ISIA members. (There is an indirectly related precedent to this as some TGs already stipulate the use of products from particular suppliers, e.g., the validated tissue models for skin and eye irritation in TGs 439 and 492, respectively). While there is currently no formal traceability geographic standard for human serum in the same way as that built for animal serum, the ISIA have initiated and contracted work on this, and the contractor has proven concept for the building of a reference database for human serum. This is necessary to underpin a traceability audit scheme (see Fig. 1). Preliminary results have demonstrated initial feasibility, and will be the basis for planning further work. The participation of the International Serum Industry Association (ISIA) (Fig. 2) will be key to the workshop, as the organization works to promote standards of excellence and ethics in the animal serum and animal derived products industry, representing and advising the suppliers of $90 \%$ of the animal serum used in life science applications worldwide, programs that have immediate relevance to the human serum market. The work underway does not yet address the issues of other human derived material such as HSA, hPL, etc.

It should be noted that the use of human serum is largely optional within the OECD Test Guideline Programme - there are currently no TGs that exclusively demand the use of human serum. Therefore, the option to use human serum allows member countries to do so when ethical sources are available, but such an approach does not exclude others from using the TG methods, as they can revert to the use of animal sera if required, and this will be the case for Japan for instance.

\section{Proposed way forward}

Although not a comprehensive review, on the basis of the breadth of the evidence provided in 2018, the OECD WNT were assured that multiple sources of human blood products are available, some of which are provided by consenting donors that do not require a (e.g., HTA) license; and some of which no longer require consent (e.g., out of date blood products, medical waste products), and that these products are available for use in the in vitro test methods. The literature evidence for the performance of these human derived products is as good as for FBS in certain applications, but there need to be substantial improvements in the rigor of documentation.

However, whilst there is currently a plentiful supply that can be distributed globally, increasing use/adaptation in TGs will potentially increase demand, and we need to ensure that the provision of such materials will not threaten donor and/or wider public support for altruistic therapeutic donation. This is an area where Japan is particularly vulnerable, with a low level of domestic blood donations. Given cultural differences with test methods that exclusively use human serum, if alternative protocols including FBS, chemically defined serum, serum free medium, etc., are not 
included in the TG, it is unlikely that such TGs will be able to be harmonized at the OECD level at the current time. Thus, the standard in vitro TG methods using FBS are available to all OECD member regulatory jurisdictions, but test method users wishing to use xeno-free TG adaptations where developed, will be able to do so, so long as the ethical and QC concerns have been adequately and demonstrably addressed.

In April 2018, the WNT agreed to undertake the following next steps, to include:

i) Instigating a workshop on sources, availability, traceability of human based reagents for TG purposes, this will be held at the OECD on March 18-19, 2019.

ii) A focus on providing CROs with guidance on acceptable sources of human serum for use in in vitro TGs, in terms of QC for safety and consistent performance, donor ethics, and informed consent regarding commercial use. This may best be achieved through dialogue and collaboration with the serum industry (via ISIA), regulators, users and other stakeholders across member countries as part of the workshop preparation and outputs.

\section{References}

Belot, N., Sim, B., Longmore, C. L. et al. (2017). Adaptation of the KeratinoSens ${ }^{\mathrm{TM}}$ skin sensitisation test to animal-product-free cell culture. ALTEX 34, 560-564. doi:10.14573/ altex. 1701311

Brown, S., Croonenborghs, B., Head, K. et al. (2018). Gamma irradiation of animal serum: Maintaining the cold chain throughout the process. BioProcess J 17. doi:10.12665/j17oa. brown

Croonenborghs, B., Pratt, A., Bone, L. and Senescu, M. (2016). Gamma irradiation of frozen animal serum: Dose mapping for irradiation process validation. BioProcess $J$ 15, 7-13. doi:10.12665/J153.croonenborghs

Edwards, A., Roscoe, L., Longmore, C. et al. (2018). Adaptation of the human cell line activation test (h-CLAT) to animal-product-free conditions. ALTEX 35, 477-488. doi:10.14573/ altex. 1710051

Gstraunthaler, G., Rauch, C., Feifel, E. and Lindl, T. (2015). Preparation of platelet lysates for mesenchymal stem cell culture media. J Stem Cells Res Rev Rep 2, 1021.

More, S., Bicout, D., Botner, A. et al. (2017). Animal welfare aspects in respect of the slaughter or killing of pregnant livestock animals (cattle, pigs, sheep, goats, horses). EFSA J 15, 4782. doi:10.2903/j.efsa.2017.4782

NHSBT - National Health Service Blood and Transplant (2018). Non Clinical Issue ('NCI') Customer Guide Information document INF965/2.1 Effective 28/03/2018. http://hospital.blood. co.uk/components/non-clinical-issue/
Nielsen, O. B. and Hawkes, P. W. (2019). Fetal bovine serum and the slaughter of pregnant cows: Animal welfare and ethics. BioProcess J 18. doi:10.12665/j18oa.hawkes

OECD - Organisation for Economic Cooperation and Development (2018a). Test No. 442D: In Vitro Skin Sensitisation: ARE-Nrf2 Luciferase Test Method. OECD Guidelines for the Testing of Chemicals, Section 4. OECD Publishing, Paris. doi:10.1787/9789264229822-en

OECD (2018b). Guidance Document on Good In Vitro Method Practices (GIVIMP). OECD Series on Testing and Assessment. OECD Publishing, Paris. doi:10.1787/20777876

Shahdadfar, A., Frønsdal, K., Haug, T. et al. (2005). In vitro expansion of human mesenchymal stem cells: Choice of serum is a determinant of cell proliferation, differentiation, gene expression, and transcriptome stability. Stem Cells 23, 13571366. doi:10.1634/stemcells.2005-0094

Strunk, D., Lozano, M., Marks, D. C. et al. (2018a). International forum on GMP-grade human platelet lysate for cell propagation: Summary. Vox Sang 113, 80-87. doi:10.1111/vox.12593

Strunk, D., Lozano, M., Marks, D. C. et al. (2018b). International Forum on GMP-grade human platelet lysate for cell propagation. Vox Sang 113, e1-e25. doi:10.1111/vox.12594

van der Valk, J. and Gstraunthaler, G. (2017). Fetal bovine serum (FBS) - A pain in the dish? Altern Lab Anim 45, 329-332.

van der Valk, J., Bieback, K., Buta, C. et al. (2018). Fetal bovine serum (FBS): Past - Present - Future. ALTEX 35, 99-118. doi:10.14573/altex.1705101

Versteegen, R., Plavsic, M., Nims, R. et al. (2016). Gamma irradiation of animal serum: An introduction. BioProcess $J$ 15, 5-11. doi:10.12665/j152.versteegen

\section{Conflict of interest}

MNJ is an employee of Public Health England, and received no industry funding to lead and coordinate this work. She has no conflict of interest. RV is CEO of the International Serum Industry Association. CT is Founder of a CRO using and developing xeno-free (animal-product-free) methods and JM is Director of a company manufacturing both serum and serum-free products, Director, AQIX Ltd, and Trustee of the Charity "What is Biotechnology". The ALTEX publication processing charges were paid for by Public Health England. The serum industry have not contributed financially to this paper.

\section{Acknowledgments}

The authors would like to thank the National Coordinators, colleagues and contacts in various member countries for their valuable input to the initial draft paper discussed in April 2018. 